\title{
PERBANDINGAN NILAI INDEX PEMAMPATAN BERDASARKAN RUMUSAN EMPIRIS DAN PENGUJIAN KONSOLIDASI
}

\author{
Putu Tantri K.Sari dan Yudhi Lastiasih \\ Departement Teknik Sipil, Fakultas Teknik Sipil,Lingkungan dan Kebumian,Institut Teknologi Sepuluh Nopember, \\ Surabaya \\ E-mail:tantrigeoteknik@gmail.com,yudhi.lastiasih@gmail.com
}

\begin{abstract}
ABSTRAK: Pengujian konsolidasi di laboratorium untuk mendapatkan nilai index pemampatan (Cc) membutuhkan waktu yang sangat lama dan harganya relative mahal, sehingga perumusan empiris lebih disukai dalam penerapan untuk perencanaan. Rumusan empiris untuk memperoleh Cc sudah dikembangkan sejak tahun 1940an di berbagai negara, namun masih sedikit rumusan empiris yang berasal dari tanah lempung lunak di Indonesia padahal karakteristik antara tanah di Indonesia dengan tanah di negara lain belum tentu sama. Perencana di Indonesia umumnya menggunakan rumusan-rumusan empiris yang telah ada dengan tujuan untuk mempersingkat waktu perencanaan padahal rumusan empiris tersebut belum tentu sesuai dengan kondisi di lapangan. Penelitian ini dilakukan untuk mengetahui perbedaan nilai Ce dari rumusan empiris dan dari pengujian di laboratorium dengan melakukan perbandingan nilai $\mathrm{Cc}$ hasil pengujian yang telah ada yaitu sebanyak 466 sampel data tanah dari 77 titik bore hole pada 25 lokasi yang tersebar di wilayah Surabaya, Indonesia. Hasil perbandingan menunjukkan bahwa nilai Cc dari 28 rumusan empiris yang telah dikembangkan sebelumnya memiliki tingkat kesamaan yang relative kecil yaitu kurang dari $70 \%$ dari nilai Ce hasil pengujian di laboratorium. Rumusan empiris nilai Cc dari data yang digunakan dalam penelitian ini juga telah didapatkan tetapi dengan variasi yang banyak karena rentang perbedaan nilai Cc yang relative besar.
\end{abstract}

Kata Kunci : Index pemampatan, compression index, Cc, pemampatan tanah, konsolidasi tanah

\section{PENDAHULUAN}

Nilai index pemampatan $(\mathrm{Cc})$ sangat diperlukan oleh para ahli geoteknik untuk mengetahui besarnya pemampatan dari tanah lempung lunak. Nilai pemampatan tersebut diperlukan untuk melakukan banyak sekali perencanaan dari membangun rumah tinggal sederhana hingga membangun jalan tol. Perhitungan pemampatan ini dianggap sangat penting untuk menghindari adanya differential settlement yang mengakibatkan adanya retak pada struktur bangunan yang berada di atas pondasi dangkal. Apabila perhitungan pemampatan ditiadakan, maka bahaya kerusakan struktur tentu saja dapat terjadi yang berakibat pada besarnya harga perbaikan struktur bangunan tersebut.

Nilai Cc sangat menentukan dalam perhitungan pemampatan, selain nilai karakteristik tanah yang lain seperti angka pori dan berat volume tanah. Namun pengujian nilai $\mathrm{Cc}$ di laboratorium lebih membutuhkan banyak waktu dan harganya relative mahal dibandingkan dengan pengujian karakteristik tanah yang lainnya. Sebagai perbandingan, perhitungan nilai berat volume dan angka pori tanah dapat selesai dalam waktu 1 hari sedangkan perhitungan nilai $\mathrm{Cc}$ maupun parameter pemampatan lainya dengan menggunakan uji konsolidasi satu dimensi di laboratorium baru akan selesai dalam waktu kurang lebih 1 minggu. Padahal perencana biasanya membutuhkan data tersebut dengan cepat, sehingga penggunaan rumusan empiris lebih disukai.

Banyak sekali rumusan pendekatan empiris yang telah dihasilkan dari jenis tanah lempung lunak dibeberapa negara berkembang. Perumusan empiris tersebut didapatkan dari mengorelasikan nilai-nilai konsistensi dan karakteristik tanah yang lebih mudah diuji di laboratorium. Beberapa prediksi perumusan empiris berdasarkan nilai Liquid limit telah dilakukan oleh Skempton (1944); Terzaghi\&Peck (1967) dan Bowles (1979); Rumusan empiris berdasarkan nilai Platicity Index telah dilakukan oleh Jian-Hua Yin (1999), AmithNath dan DeDalal (2004) dan rumusan empiris berdasarkan nilai Shringkage Index telah dilakukan oleh
Sridharan dan Nagrai (2001). Rumusan-rumusan lain juga sudah banyak diperoleh dari pengujian yang telah dilakukan dibeberapa Negara antara lain : Azzouz dkk (1976) yang melakukan pengujian tanah lempung Chicago, lempung Brazilian, lempung Motley dari kota San Paulo, lempung di USA serta lempung di Mesir berdasarkan nilai kadar air, angka pori dan Liquid Limit. Nacci dkk (1975) telah melakukan pengujian pada lempung di North Atlantic berdasarkan nilai Index plasticity. Bukan hanya itu puluhan rumusan lainnya juga telah dikembangkan dengan mengorelasi nilai karakteristik tanah yaitu angka pori, specific Gravity dan kadar air. Beberapa rumusan tersebut diantaranya dikembangkan oleh Azzouz, Krizek and Corotis (1976); Wroth and Wood (1978); Nagaraj dan Murthy (1986;1986); Ostenberg (1972); Cozzolina (1961); Sower (1970); Moran, Proctor, Mueser dan Rutlrdge (1958). Rumusan tersebut ditawarkan untuk seluruh lempung lunak.

Rumusan-rumusan empiris yang telah berkembang dalam kurun waktu 80 tahunan tersebut sudah sangat membantu perencana dalam melakukan perhitungan desain. Namun, rumusan yang berkembang tersebut merupakan hasil dari korelasi jenis-jenis lempung yang ada dinegara lain dan bukan di Indonesia. Padahal, kondisi tanah lempung lunak di Surabaya, Indonesia belum tentu sama dengan kondisi tanah dinegara-negara lain. Sayangnya, untuk mempersingkat waktu pengujian konsolidasi dan mengurangi biaya, penggunaan rumusan empiris hasil pengujian tanah dinegara lain lebih sering digunakan oleh perencana di Indonesia.

Untuk menghindari terjadinya kesalahan perencanaan akibat dari kesalahan pemilihan rumusan empiris untuk memperoleh nilai index pemampatan, maka perlu dilakukan pengujian data tanah untuk mengetahui seberapa tepat hasil nilai $\mathrm{Cc}$ berdasarkan perumusan empiris jika dibandingkan dengan nilai $\mathrm{Cc}$ dari hasil pengujian. Selain itu, rumusan empiris yang baru berdasarkan data pengujian tanah yang sudah ada juga diperlukan sebagai pembanding dari rumusan empiris 
Jurnal Rekayasa Tenik Sipil Universitas Madura Vol. 4 No.1 Juni 2019 ISSN 2527-5542

yang sudah ada . Sebelumnya, pengujian rumusan empiris untuk lempung lunak di Indonesia sudah pernah dilakukan, namun masih dalam skala pengujian kecil di laboratorium. Pengujian dilakukan oleh Kosasih dan Mochtar (1997) yang memperoleh rumusan empiris untuk memperoleh nilai index pemampatan yang merupakan hubungan dari nilai angka pori, kadar air dan index plastisitas. Rumusan tersebut didapatkan dari pengujian beberapa sampel dilaboratorium terhadap jenis tanah lempung lunak pada nilai Liquit limit yang bervariasi. Hasil dari rumusan empiris ini sudah dapat digunakan sebagai pembanding dalam penelitian kali ini.

Data yang digunakan dalam penelitian ini adalah seluruh data pengujian tanah konsolidasi satu dimensi dengan oedometer pada tanah lempung di Surabaya. Data tersebut diperoleh dari Laboratorium Mekanika Tanah, Institut Teknologi Sepuluh Nopember Surabaya. Sampel diambil dalam rentang waktu 20 tahun terakhir yaitu dari tahun 1980an hingga 2000an karena dianggap lebih teliti dan valid hasilnya. Jumlah sampel yang dianggap layak (hanya tanah berkonsistensi Lempung saja) untuk pengujian ini diambil dari 25 lokasi di Surabaya dengan 77 jumlah borehole dan 466 sampel uji.

Tujuan dari penelitian ini adalah untuk membandingkan hasil index pemampatan dari data hasil pengujian dilaboratorium dengan perumusan-perumusan empiris yang sudah ada sebelumnya. Kemudian, apabila hasil nilai index pemampatan dengan perumusan empiris sangat jauh berbeda dari nilai pengujian konsolidasi dari data pengujian laboratorium maka dilakukan pengujian dengan menggunakan linear regresi untuk memperoleh nilai perumusan empiris untuk data tanah di Surabaya. Diharapkan, rumusan empiris yang dihasilkan ini dapat digunakan untuk menghitung nilai index pemampatan sehingga dapat mengurangi waktu dan biaya pengujian.

\section{Analisa data dan perbandingan rumusan empiris}

Hasil pengujian sampel tanah yang digunakan dalam penelitian ini dapat dilihat dari Gambar 1. Hasil pengujian di laboratorium yang digunakan dalam analisa perbandingan yaitu nilai angka pori, kadar air, konsistensi tanah berdasarkan harga liquid limit (LL), Plastis limit (PL) dan Index plastisitas (IP), berat volume tanah, specific Grafity dan berat volume terhadap nilai index pemampatan. Tanah yang diuji merupakan tanah lempung yang cenderung jenuh air dengan nilai berat volume antara 1.5 hingga $2 \mathrm{t} / \mathrm{m}^{3}$, angka pori antara 0.4 hingga 3.7 . Batasan nilai konsistensi tanah dan jenis tanah yang diuji dapat dilihat pada Gambar 2.

Salah satu pengujian sampel tanah dilakukan dengan melihat nilai konsistensi tanah dari hasil pengujian Atterberg Limit yatu berupa nilai batas cair (LL) dan batas plastis (PL). Batas cair dan batas plastis telah digunakan secara ekstensif oleh para ahli teknik sipil untuk menentukan korelasi dari beberapa parameter tanah fisis dan juga untuk mengidentifikasi tanah. Casagrande (1932) telah mempelajari index plastis dan batas cair dari bermacam-macam tanah asli yang dikemas dalam suatu bagan. Hal yang penting dalam bagan tersebut adalah garis empiris A yang memisahkan tanah lempung anorganic dan lanau anorganik. Tanah lempung anorganik terletak diatas garis A dan tanah lanau anorganik terletak di bawah garis A. Tanah lanau anorganik dengan kemampu-mampatan sedang berada dibawah garis A dengan LL yang berkisar antara $30-50$. Tanah lempung organic berada didalam daerah yang sama seperti tanah lanau anorganik dengan kemampu-mampatan tinggi (dibawah garis A dengan LL lebih besar daripada 50.

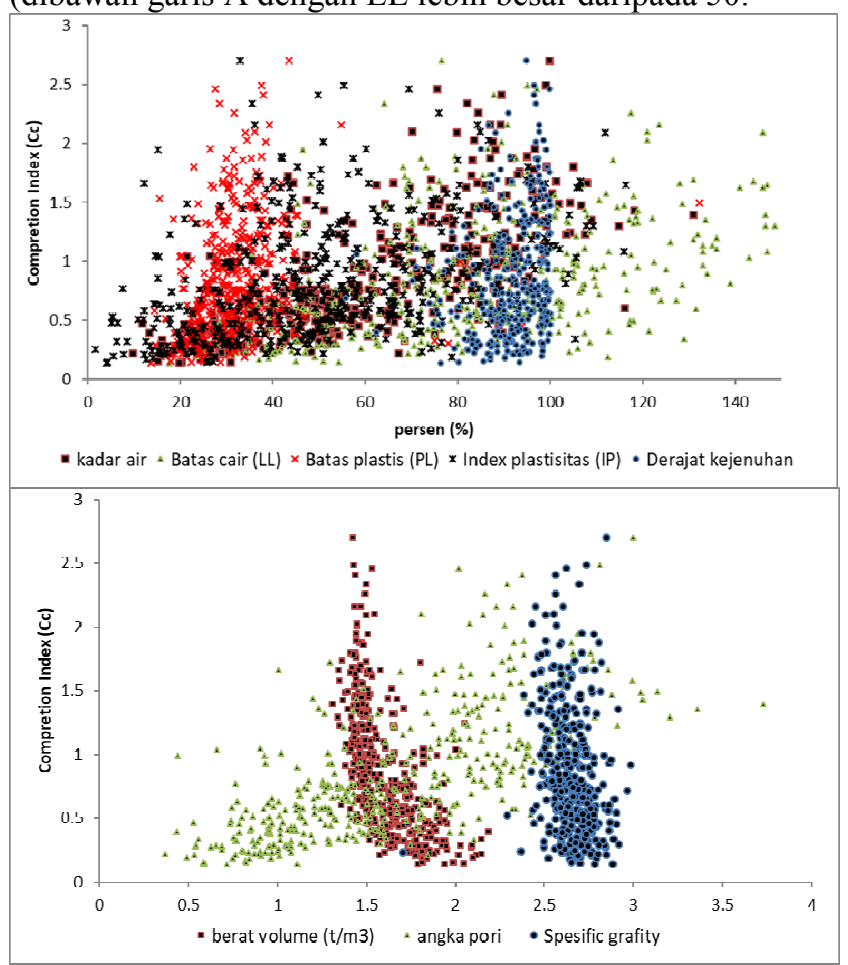

Gambar 1. Data hasil pengujian di laboratorium. (atas) Grafik hasil pengujian nilai kadar air, derajat kejenuhan, batas cair, batas plastis dan index plastisitas terhadap nilai index pemampatan (compression index (Cc)); (bawah) grafik hasil pengujian nilai berat volume, angka pori dan

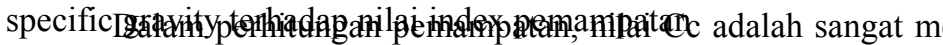
Banfyamsekessiphindex fergdekatan empiris yang telah dihas

Berdasarkan nilai konsistensi tanahnya pada Gambar 2, tanah yang digunakan dalam penelitian ini adalah didominasi dengan lempung anorganik dengan nilai plastisitas sedang hingga cenderung tinggi sampai sangat tinggi. Beberapa data yang berada diatas garis U-Line serta data tanah dibawah garis A (cenderung lanau) ditiadakan dan tidak digunakan dalam penelitian ini. Peniadaan data tersebut dilakukan karena terlalu besarnya rentang variasi nilai LL dan IP menyebabkan terlalu sulitnya memperoleh pendekatan empiris untuk memperoleh rumusan. Berdasarkan hasil peniadaan beberapa data terhadap nilai Atteberg limit dan nilai klasifikasi tanah maka dari 466 data yang ada hanya 425 sampel tanah yang layak digunakan dalam pengujian data. Setelah melakukan pengujian data tanah, kemudian dilakukan perbandingan nilai index pemampatan terhadap data laboratorium yang ada. Perbandingan data dilakukan dengan 28 rumusan empiris yang ada. Hasil dari perbandingan rumusan empiris dan hasil laboratorioum dapat dilihat pada Tabel 1.

Berdasarkan hasil pengujian pada Tabel 1, ternyata beberapa rumusan yang sudah ada hanya memiliki nilai prosentase kesamaan $<30 \%$, sedangkan beberapa rumusan lainnya memiliki prosentase kesamaan antara 30- $60 \%$, hanya satu rumusan empiris yang memiliki prosentase kesamaan data diatas $67 \%$. Sehingga dari hasil pengujian data tersebut, dapat dilihat bahwa rumusan 
Jurnal Rekayasa Tenik Sipil Universitas Madura Vol. 4 No.1 Juni 2019 ISSN 2527-5542

empiris yang sudah ada masih belum bisa mewakili data tanah yang ada di Surabaya. Berdasarkan kenyataan yang ada maka perlu dilakukan pengujian data laboratorium tersebut untuk memperoleh rumusan empiris yang sesuai dengan kondisi data tanah di Surabaya. Penggunaan regresi Linear dilakukan dalam memperoleh rumusan empiris pada data tanah ini.

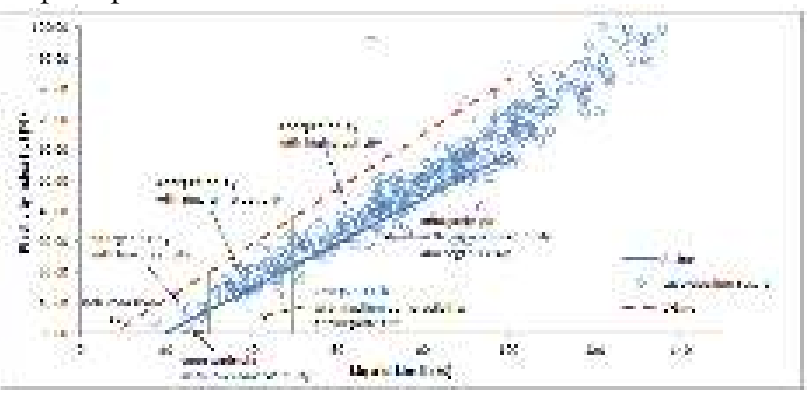

\begin{tabular}{|l|l|c|}
\hline $\mathrm{Cc}=0.5 . \mathrm{Gs} . \mathrm{PI}$ & $\begin{array}{l}\text { C. P. Wroth and D. M. } \\
\text { Wood (1978) }\end{array}$ & 33.02 \\
\hline $\mathrm{Cc}=0.2343 \mathrm{Wc} . \mathrm{Gs}$ & $\begin{array}{l}\text { T. S. Nagaraj and B. } \\
\text { R. Murthy (1985) }\end{array}$ & 22.64 \\
\hline $\begin{array}{l}\mathrm{Cc}=0.009 \mathrm{Wc}+0.002 . \text { LL- } \\
0.10\end{array}$ & $\begin{array}{l}\text { T. S. Nagaraj and B. } \\
\text { R. Murthy (1986) }\end{array}$ & 53.77 \\
\hline $\mathrm{Cc}=0.01(\mathrm{Wc}-5)$ & $\begin{array}{l}\text { Azzouz (1976) USA } \\
\text { and Greece Clay }\end{array}$ & 45.75 \\
\hline $\mathrm{Cc}=0.01 \mathrm{Wc}$ & $\begin{array}{l}\text { Ostenberg (1972) All } \\
\text { Natural soil }\end{array}$ & 52.12 \\
\hline $\begin{array}{l}\mathrm{Cc}=0.256+0.43(\mathrm{eo}- \\
0.84)\end{array}$ & $\begin{array}{l}\text { Cozzolina (1961) } \\
\mathrm{Cc}=1.21+1.055(\mathrm{eo}-1.87)\end{array}$ & 53.30 \\
\hline $\mathrm{Cc}=0.75(\mathrm{eo}-0.5)$ & $\begin{array}{l}\text { Cozzolina (1961) } \\
\text { power (1970) for low }\end{array}$ & 35.85 \\
\hline $\mathrm{Cc}=(\mathrm{Wc} / 100)-0.05$ & Azzouz (1976) & 45.99 \\
\hline $\mathrm{Cc}=1.15 .10^{\wedge}-2 . \mathrm{Wc}$ & $\begin{array}{l}\text { Moran,Proctor,Mueser } \\
\text { and Rutlrdge (1958) }\end{array}$ & 55.42 \\
\hline
\end{tabular}

Gambar 2. Bagan plastisitas untuk data tanah di Surabaya.

Tabel 1. Prosentase nilai kesamaan dari nilai $\mathrm{Cc}$ berdasarkan hasil rumusan empiris terhadap hasil laboratorium data tanah yang ada.

\begin{tabular}{|c|c|c|}
\hline Rumusan & Keterangan & $\begin{array}{c}\% \\
\text { kesamaan }\end{array}$ \\
\hline $\mathrm{Cc}=0.009(\mathrm{LL}-10)$ & $\begin{array}{l}\text { Terzhagi Peck (1967) } \\
\text { undisturbed }\end{array}$ & 67.69 \\
\hline $\mathrm{Cc}=0.007(\mathrm{LL}-10)$ & $\begin{array}{l}\text { Terzhagi Peck (1967) } \\
\text { remolded }\end{array}$ & 42.69 \\
\hline $\mathrm{Cc}=0.01 . \mathrm{Wc}$ & $\begin{array}{l}\text { Azzouz dkk (1976) } \\
\text { Chicago clay }\end{array}$ & 52.36 \\
\hline $\mathrm{Cc}=0.0046(\mathrm{LL}-9)$ & $\begin{array}{l}\text { Azzouz dkk (1976) } \\
\text { Brazilian clay }\end{array}$ & 29.48 \\
\hline $\mathrm{Cc}=1.21+1.005(\mathrm{eo}-1.87)$ & $\begin{array}{l}\text { Azzouz dkk (1976) } \\
\text { Motley Clays from } \\
\text { Sao Paulo City }\end{array}$ & 38.21 \\
\hline $\mathrm{Cc}=0.208 \mathrm{eo}+0.0083$ & $\begin{array}{l}\text { Azzouz dkk } \\
\text { (1976)Chicago clay }\end{array}$ & 26.89 \\
\hline $\mathrm{Cc}=0.02+0.014(\mathrm{PI})$ & $\begin{array}{l}\text { Nacci dkk (1975) } \\
\text { North Atlantic clay }\end{array}$ & 38.44 \\
\hline $\begin{array}{l}\mathrm{Cc}=0.141 . \mathrm{Gs}^{\wedge} 1.2 \\
((1+\mathrm{e} 0) / \mathrm{Gs})^{\wedge} 2.38\end{array}$ & Rendo-Herrero (1983) & 34.91 \\
\hline $\mathrm{Cc}=0.156 \mathrm{eo}+0.0107$ & $\begin{array}{l}\text { Hough (1957) all } \\
\text { clays }\end{array}$ & 20.05 \\
\hline $\mathrm{Cc}=1.15($ eo- -0.27$)$ & $\begin{array}{l}\text { Nishida (1956) All } \\
\text { clay }\end{array}$ & 10.14 \\
\hline $\mathrm{Cc}=0.30(\mathrm{eo}-0.27)$ & Rendo-Herrero (1980) & 31.84 \\
\hline $\mathrm{Cc}=0.4049($ eo- 0.3216$)$ & $\begin{array}{l}\text { Hough (1957) } \\
\text { Inorganic cohesive } \\
\text { soil: silt, silty clay, } \\
\text { clay }\end{array}$ & 46.23 \\
\hline $\mathrm{Cc}=0.0102(\mathrm{Wc}-9.15)$ & $\begin{array}{l}\text { Hough (1957) } \\
\text { Inorganic cohesive } \\
\text { soil: silt, silty clay, } \\
\text { clay }\end{array}$ & 41.51 \\
\hline $\mathrm{Cc}=0.4(\mathrm{eo}-0.25)$ & $\begin{array}{l}\text { Azzouz (1976)Clay } \\
\text { USA and Greece }\end{array}$ & 49.76 \\
\hline $\begin{array}{l}\mathrm{Cc}=0.007 \mathrm{LL}+0.0001 \\
\mathrm{Wc} c^{\wedge}-0.18\end{array}$ & $\begin{array}{l}\text { Kosasih dan Mochtar } \\
\text { (1997), Surabaya clay } \\
\text { based from lab.testing }\end{array}$ & 46.46 \\
\hline $\begin{array}{l}\mathrm{Cc}=0.006 \mathrm{LL}+0.13 \mathrm{eo}^{\wedge} 2- \\
0.13\end{array}$ & $\begin{array}{l}\text { Kosasih dan Mochtar } \\
\text { (1997), Surabaya clay } \\
\text { based from lab.testing }\end{array}$ & 48.82 \\
\hline $\begin{array}{l}\mathrm{Cc}=0.37(\mathrm{eo}+0.003 \mathrm{LL}- \\
0.34)\end{array}$ & $\begin{array}{l}\text { A. S. Azzouz, R. J. } \\
\text { Krizek, and R. B. } \\
\text { Corotis (1976) } \\
\end{array}$ & 50.71 \\
\hline $\begin{array}{l}\mathrm{Cc}=- \\
0.156+0.41 \mathrm{eo}+0.00058 \mathrm{Wc}\end{array}$ & $\begin{array}{l}\text { A. S. Azzouz, R. J. } \\
\text { Krizek, and R. B. } \\
\text { Corotis (1976) }\end{array}$ & 47.88 \\
\hline
\end{tabular}

\section{Hasil Analisa dan Regresi Linear}

Perumusan empiris dilakukan dengan menggunakan regresi linear dengan mencari nilai $\mathrm{R}^{2}$ yang mendekati 1 . $\mathrm{R}^{2}$ sering disebut dengan koefisien determinasi,fungsinya adalah mengukur tingkat kesesuaian (goodness of fit) dari persamaan regresi; yaitu memberikan proporsi atau persentase variasi total dalam variabel terikat yang dijelaskan oleh variabel bebas. Nilai $\mathrm{R}^{2}$ terletak antara $0-$ 1 , dan kecocokan model dikatakan lebih baik kalau $\mathrm{R}^{2}$ semakin mendekati 1.

Perhitungan perumusan dilakukan terhadap 425 data tanah yang telah dikumpulkan dibandingkan dengan 28 rumusan empiris yang telah ada sebelumnya. Hasil dari perumusan pada seluruh data yang ada menunjukan nilai $\mathrm{R}^{2}$ yang lebih kecil dari 0.5 , sehingga dilakukan berbagai sortir data serta pengelompokan data berdasarkan nilai Liquid limit dan plastisitas limit yang dibatasi untuk memperoleh nilai $\mathrm{R}^{2}$ yang lebih tinggi. Beberapa hasil dari perumusan dapat dilihat pada Gambar 3a dan $3 b$. Hasil perbandingan rumusan menunjukkan bahwa terdapat perbedaan yang cukup signifikan dari rumusanrumusan empiris yang sudah ada dan hasil pengujian data tanah di laboratorium.

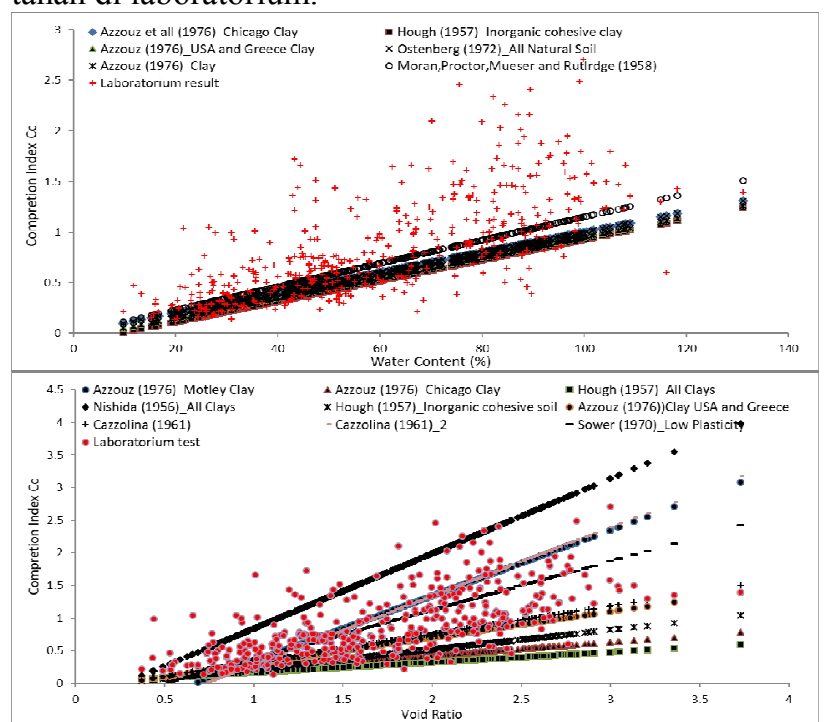

Gambar 3a (atas) . Grafik hubungan nilai Cc dengan angka pori antara rumusan empiris dan data laboratorium.Gambar 3b (bawah). Grafik hubungan nilai Cc dengan kadar air antara rumusan empiris dan data laboratorium 
Perhitungan rumusan empiris dilakukan dengan menggunakan pengelompokan nilai Liquit limit dan nilai Index plastisitas. Hal tersebut dilakukan karena sebaran data yang terlalu besar mengakibatkan nilai $\mathrm{R}$ square lebih kecil dari 0.5 sehingga kecocokan model dikatakan kurang baik. Untuk mendekati nilai $\mathrm{R}$ square menjadi 1 maka pengelompokan berdasarkan nilai plastisitas dari tanah perlu dilakukan. Hasil dari regresi linier untuk rumusan empiris dari pengelompokan nilai Liquid limit dapat dilihat pada Gambar 4a dan 4b.
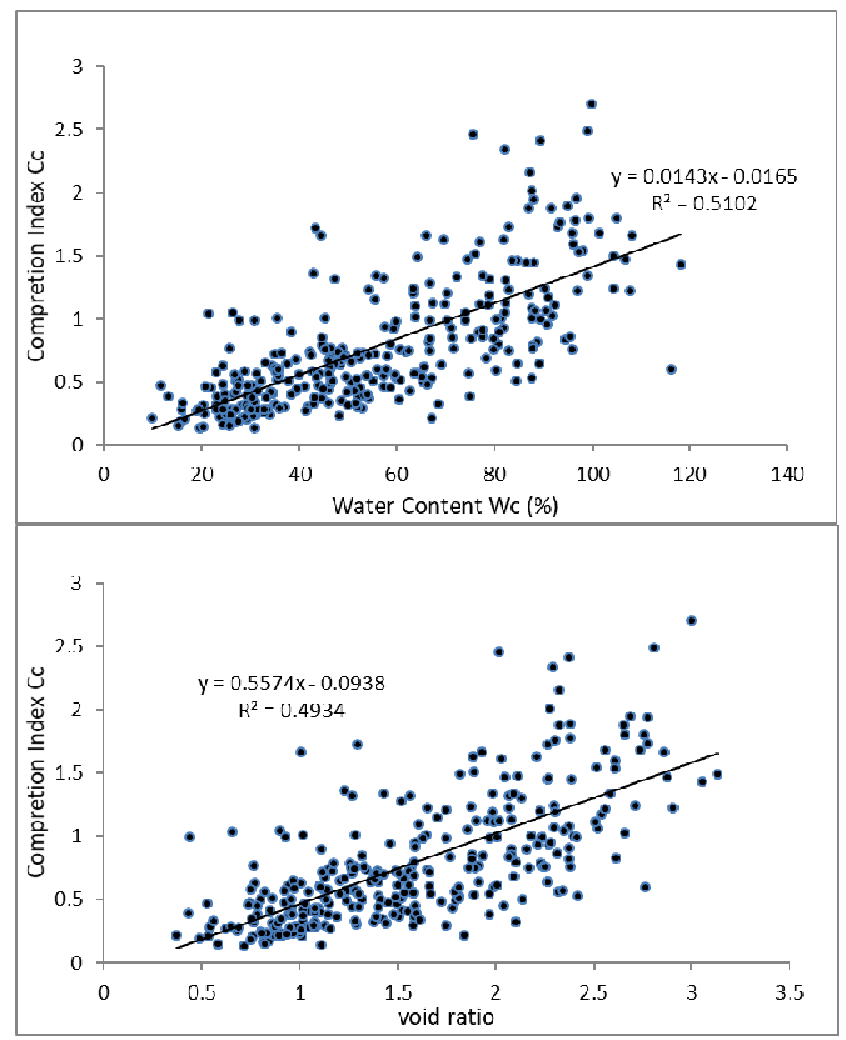

Gambar 4a. Grafik hubungan index pemampatan (Cc) dengan Kadar air (Wc (\%)) dan angka pori (eo) dengan nilai LL $0-100 \%$

Selain pengelompokan berdasarkan nilai Liquit limit, juga dikelompokkan berdasarkan nilai index plastisitas. Nilai index plastisitas dikelompokkan menjadi 0-70\% sesuai dengan batasan pada bagan plastisitas dan 0-120\% sesuai dengan nilai IP pada seluruh sampel tanah. Menurut Skempton (1953) nilai indeks plastisitas suatu tanah bertambah menurut garis lurus sesuai dengan bertambahnya prosentase dari fraksi berukuran lempung yang dikandung oleh tanah. Semakin meningkat nilai IP maka prosentase fraksi lempung halus semakin besar. Sehingga pembatasan nilai IP ini dilakukan untuk membatasi nilai lempung yang terlalu lunak dan berplastisitas tinggi. Gambar 5 menunjukan kurva hubungan nilai index pemampatan terhadap nilai kadar air dan angka pori dengan batasan nilai IP.

Hasil dari regresi linear terhadap data-data yang ada menunjukkan bahwa terdapat beragam nilai rumusan empiris dengan nilai $\mathrm{R}^{2}$ yang berbeda-beda pula pada setiap pengelompokan data yang telah dilakukan. Rekapitulasi hasil perumusan dan nilai $\mathrm{R}^{2}$ dapat dilihat pada Tabel 2.
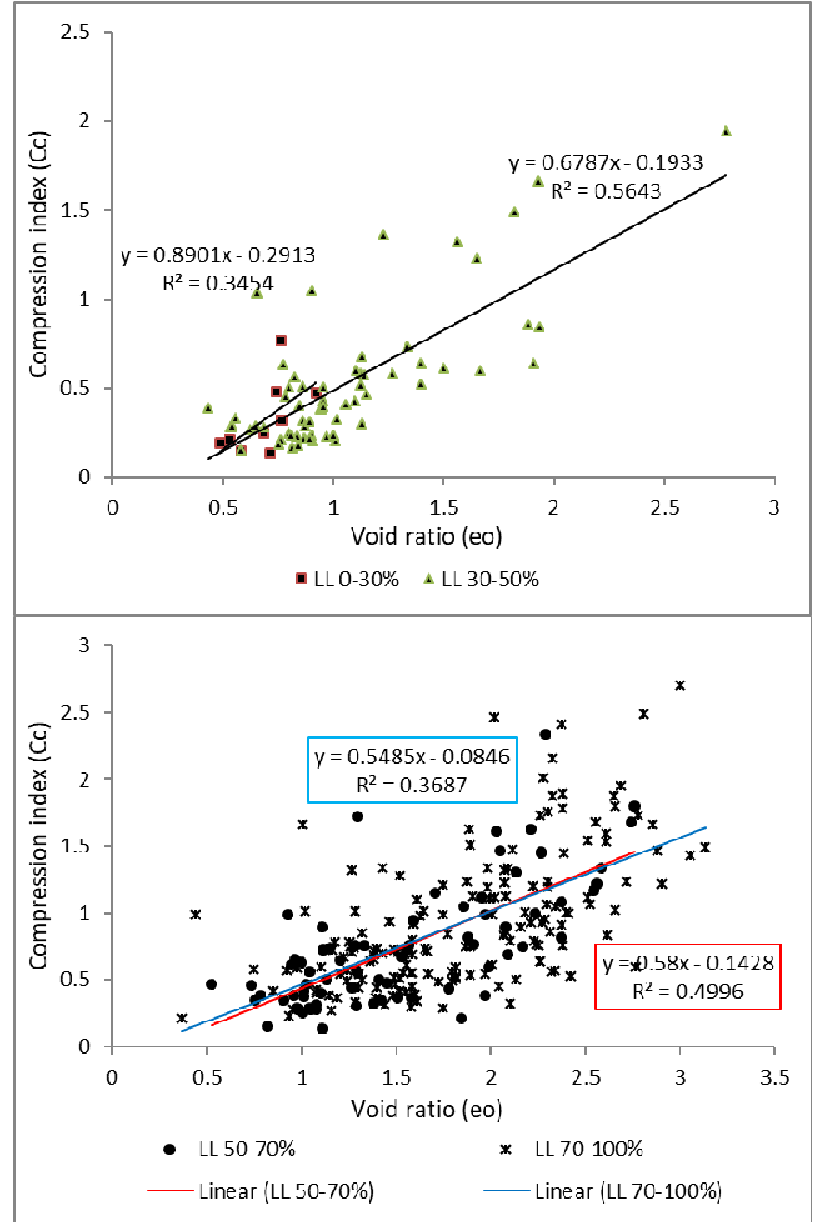

Gambar 4b. Grafik hubungan index pemampatan (Cc) dengan Kadar air (Wc (\%)) dan angka pori (eo) dengan nilai LL dikelompokkan.
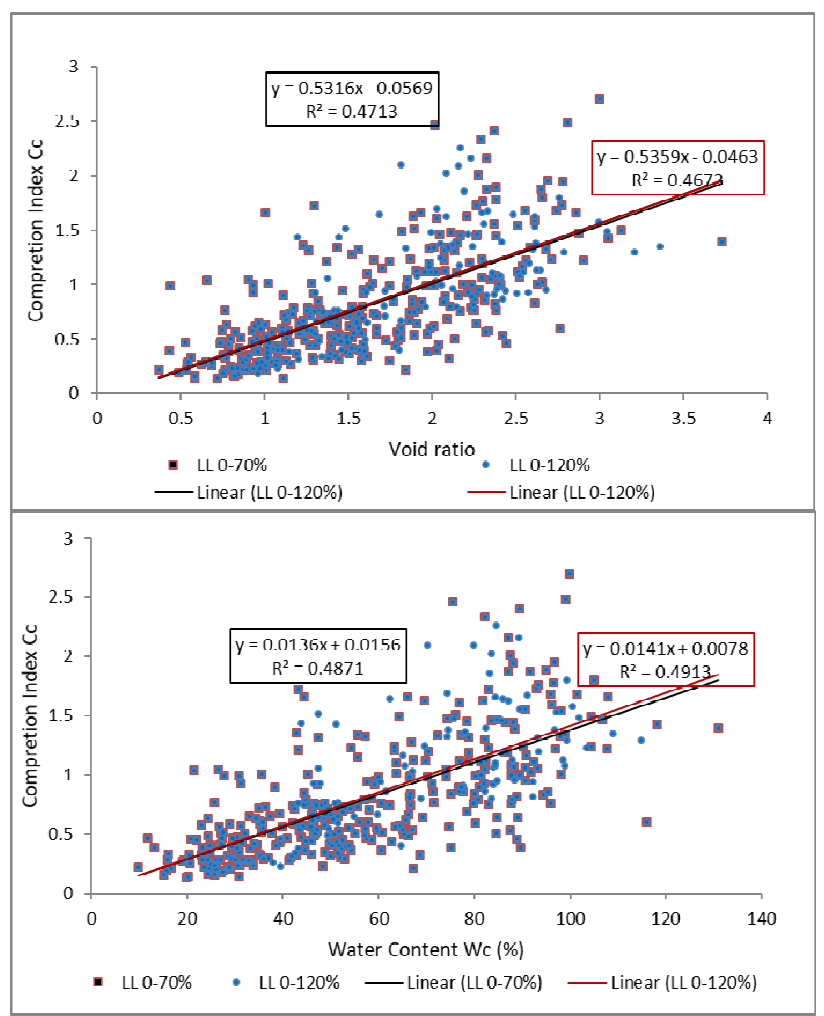

Gambar 5. Grafik hubungan index pemampatan (Cc) dengan Kadar air (Wc (\%)) dan angka pori (eo) dengan nilai IP dikelompokkan. 
Jurnal Rekayasa Tenik Sipil Universitas Madura Vol. 4 No.1 Juni 2019 ISSN 2527-5542

Tabel 2 Rekapitulasi Hasil Perumusan Dan Nilai R ${ }^{2}$

\begin{tabular}{|c|c|c|}
\hline Batasan & Rumusan empiris & $\mathrm{R}^{2}$ \\
\hline $\begin{aligned} \mathrm{LL} & =0-150 \% ; \mathrm{IP} \\
& =0-70 \%\end{aligned}$ & $\mathrm{Cc}=0.0136 \mathrm{Wc}+0.0156$ & 0.4871 \\
\hline $\begin{aligned} \mathrm{LL} & =0-150 \% ; \mathrm{IP} \\
& =0-120 \%\end{aligned}$ & $\mathrm{Cc}=0.0141 \mathrm{Wc}+0.0078$ & 0.4913 \\
\hline $\begin{aligned} \mathrm{LL} & =0-100 \% ; \mathrm{IP} \\
& =0-70 \%\end{aligned}$ & $\mathrm{Cc}=0.0143 \mathrm{Wc}-0.0165$ & 0.5102 \\
\hline $\begin{aligned} \mathrm{LL} & =0-100 \% ; \mathrm{IP} \\
& =0-70 \%\end{aligned}$ & $\mathrm{Cc}=6.23 \mathrm{Wc}$ & 0.5099 \\
\hline $\begin{aligned} \mathrm{LL} & =0-100 \% ; \mathrm{IP} \\
& =0-70 \%\end{aligned}$ & $\mathrm{Cc}=0.4044(\mathrm{eo}+0.01 \mathrm{Wc})-0.0795$ & 0.5024 \\
\hline $\begin{aligned} \mathrm{LL} & =0-100 \% ; \mathrm{IP} \\
& =0-70 \%\end{aligned}$ & $\begin{array}{c}\mathrm{Cc}=1.0941(0.123 \mathrm{eo}+0.01 \mathrm{Wc})- \\
0.0415\end{array}$ & 0.5101 \\
\hline $\begin{aligned} \mathrm{LL} & =0-100 \% ; \mathrm{IP} \\
& =0-70 \%\end{aligned}$ & $\begin{array}{c}\mathrm{Cc}=0.2867(1.567 \mathrm{eo}+0.01 \mathrm{Wc})- \\
0.0843\end{array}$ & 0.5001 \\
\hline $\mathrm{LL}=0 \%-30 \%$ & $\mathrm{Cc}=0.0327 \mathrm{Wc}-0.3819$ & 0.5265 \\
\hline $\mathrm{LL}=30 \%-50 \%$ & $\mathrm{Cc}=0.6787 \mathrm{eo}-0.1933$ & 0.5643 \\
\hline $\mathrm{LL}=30 \%-50 \%$ & $\mathrm{Cc}=0.0179 \mathrm{Wc}-0.1005$ & 0.5341 \\
\hline $\mathrm{LL}=50 \%-70 \%$ & $\mathrm{Cc}=0.58 \mathrm{eo}-0.1428$ & 0.4996 \\
\hline $\mathrm{LL}=50 \%-70 \%$ & $\mathrm{Cc}=0.0137 \mathrm{Wc}+0.0034$ & 0.4980 \\
\hline
\end{tabular}

Hasil pada Tabel 2 menunjukan bahwa rentang variasi data nilai index pemampatan $(\mathrm{Cc})$ adalah terlalu besar sehingga menghasilkan rumusan dengan nilai $\mathrm{R}^{2}$ yang kurang dari $60 \%$. Hasil yang sama juga dibuktikan oleh Sari dkk (2013) yang menghasilkan suatu rumusan empiris dengan $\mathrm{R}^{2}$ antara 30-70\%. Al-Khafaji dkk (1992) pernah melakukan penelitian untuk memperoleh rumusan untuk mendapatkan nilai $\mathrm{Cc}$. Penelitian tersebut terus dilakukan hingga saat ini. Penelitian terbaru mengenai nilai index pemampatan terhadap nilai batas cair (LL) dilakukan oleh Al-Khafaji (2019) yang menyatakan bahwa persamaan empiris yang telah dipublikasikan sebelumnya untuk memperoleh perkiraan indeks kompresi menunjukkan ketidakkonsistenan yang cukup besar. Penelitian tersebut dilakukan pada lebih dari 1900 data nilai $\mathrm{Cc}$ dan LL pada suatu tanah. Ketidak konsistenan hasil tersebut secara langsung dikaitkan dengan sifat data yang digunakan dalam pengembangan hubungan empiris. Seringkali, informasi yang berkaitan dengan sejarah tegangan pada tanah dan jenis tanah tidak ada secara detail.

\section{Kesimpulan}

Berdasarkan hasil analisa perbandingan rumusan empiris yang sudah ada dengan sampel data tanah menunjukkan bahwa, terdapat perbedaan nilai Cc antara rumusan empiris dengan hasil data tanah dari pengujian laboratorium. Prosentase nilai index pemampatan yang sesuai dengan hasil pengujian dilaboratorium adalah $<$ $70 \%$ sehingga rumusan empiris yang sudah ada belum bisa mewakili nilai index pemampatan tanah lempung di Surabaya. Pendekatan nilai karakteristik data tanah untuk mendapatkan suatu rumusan menghasilkan beberapa rumusan empiris dengan nilai $\mathrm{R}^{2}$ sekitar 0,5 . Pengelompokan data nilai LL dan IP dilakukan untuk memperoleh nilai $\mathrm{R}^{2}$ yang mendekati 1 . Namun belum bisa memperoleh nilai $\mathrm{R}^{2}$ mendekati 1 . Nilai maksimal yang diperoleh adalah 0.5643 untuk rumusan empiris $\mathrm{Cc}=0.6787$ eo-0.1933 yang artinya bahwa kecocokan model yang dihasilkan dari rumusan empiris tersebut hanya memenuhi sebagian dari data sampel yang diuji. Sehingga untuk memperoleh rumusan empiris dengan nilai $\mathrm{R}^{2}$ yang mendekati 1 diperlukan lebih banyak data lagi. Selain itu pengujian laboratorium ulang pada beberapa sampel tanah di Surabaya juga perlu dilakukan sebagai pembanding dari hasil pengujian data tanah yang sudah dilakukan sebelumnya. Penelitian lanjutan masih perlu dilakukan untuk memperoleh rumusan empiris yang lebih mendekati nilai yang ada serta juga perlu dilakukan pengujian kelayakan data laboratorium yang sudah ada.

\section{Daftar Pustaka}

Al Khafaji A. W. N. and O. B. Andersland, (1992), Equations for Compression Index Approximation, Journal of Geotechnical Engineering, ASCE, 118, 148-155.

Al-Khafaji A., Buehler A., Druszkowski E. (2019) Validation of Compression Index Approximations Using Soil Liquid Limit. In: Hemeda S., Bouassida M. (eds) Contemporary Issues in Soil Mechanics. GeoMEast 2018. Sustainable Civil Infrastructures. Springer, Cham

Amitnath and Dedalal S.S, (2004), The role of plasticity index in predicting Compression Index behaviour of clays, Electronic Journal of Geotechnical Engineering http://www. ejge.com/2004/Per0466/Ppr0466.htmm.

Azzouz A.S., R. J. Krizek, and R. B. Corotis, (1976), Regression Analysis of Soil Compressibility, Soils and Foundations, 16(2),19-29.

Bowles J.W., (1979), Physical and Geotechnical Properties of Soils, New York: McGraw Hill.

C. P. Wroth D. M.,(1978), Wood The correlation of index properties with some basic engineering properties of soils, Canadian Geotechnical Journal, 15(2): 137145.

G. B. Sowers, (1970), Introductory Soil Mechanics and Foundations, Macmillan Co., New York, 1951, 3rd edition.

Jian-Hua Yin, (1999), Properties and Behaviour of Hong Kong Marine Deposits with Different Clay Contents, Canadian Geotechnical Journal, Vol 36, pp. 1085 1095.

Karl Terzaghi, Ralph Peck. (1967), Soil Mechanics in Engineering Practice, 2nd Edition. John Wiley, New York.

Kosasih.,A., Mochtar.,I.B.,(1997)., Pengaruh Kadar Air, Angka Pori, dan Batas Cair Tanah Lempung Terhadap Indeks Pemampatan Konsolidasi Cc dan Indeks Pengembangan Cs., Master Thesis, Program Pasca Sarjana, teknik Sipil ITS.

Moran, Proctor, Mueser, and Rutledge, (1958), Study of deep soil stabilization by vertical sand drains. Report to Bureau of Yards and Docks, Department of the Navy, Washington, D.C.

Nishida Y. (1956), A Brief Note on the Compression Index of Soil, Journal of Soil Mechanics and. Foundation Division, American Society y of Civil Engineers, Vol 82, No.3, pp1-

Nagaraj.,T. S. and B. R. Murthy, (1985), Prediction of the Preconsolidation Pressure and Recompression Index of Soils, Geotechnical Testing Journal, ASTM, 8(4),199-202.

Nagaraj, T. S. and B. R. Murthy,(1986), A Critical Reappraisal of Compression Index, Geotechnique, $36(1), 27-32$. 
Osterberg, J. O., (1957), Introduction of the symposium on vane shear testing of soils, Am. Soc. Testing Mater., Spec. Tech. Publ., 193: 1-7.

Rendon-Herrero.,O., (1980),Universal Compression Index Equation, Journal of the Geotechnical Engineering Division, American Society of Civil Engineering, 106(11), 1179-1200.

Sari,P.T.K, Firmansyah (2013), The Empirical Correlation Using Linear Regression of Compression Index for Surabaya Soft Soil,Advances in Structural Engineering and Mechanics (ASEM13), Jeju,Korea.

Skempton.,A.W.,(1944), Notes on The Compressibility of Clays, J.Geo. Soc.London (C:parts 1\&2), 100, 119135.

Skempton A.W. (1944), Notes on the Compressibility of Clays", J.Geo. Soc.London (C:parts 1\&2), 100, 119135.

Sridharan A, and Nagaraj H.B, (2001), Compressibility behaviour of remolded fine-grained soils and correlation with index properties, Canadian Geotechnical Engineering Journal, No. 38, pp. 11391154.

V.A. Nacci, M.C. Wang, K.R. Demars, (1975), Engineering behavior of calcareous soils, Civil Engineering in the Oceans III, ASCE, Newark.

V.M. Cozzolino., (1961), Statistical forecasting of compression index, The 5th International Conference on Soil Mechanics and Foundation Engineering, Paris.

Wroth C.P. and D. M. Wood, (1978), The Correlation of Index Properties with Some Basic Engineering Properties of Soils, Canadian Geotechnical Journal, 15(2), 137-145. 